\title{
Türkçe Kimya Terimleri Sözlükleri Üzerine Bir Değerlendirme
}

\author{
An Evaluation of the Chemistry Terms recorded in Turkish Dictionaries
}

\begin{abstract}
Ali CiN *
Günseli TURGUT CìN **

$\ddot{O}_{z:}$ Bilindiği üzere bir sanat, meslek ya da bilim dalıyla ilgili kavramları karşılayan kelimelere terim, ya da eskiden kullanılan biçimiyle istılah diyoruz. Eski dilimizde simya, modern adıyla kimya alanında her geçen gün yeni ve hızlı gelişmeler olmakta ve bunun sonucunda da tüm dünya dillerinde bu hızlı ilerleyişe uyum sağlayabilmek için yeni kelime ve terimlere ihtiyaç duyulmaktadır. Her spesifik alanda olduğu gibi kimya biliminde de, tüm sahayı kapsayacak yeterli terimleri içeren sözlükler, yeni yeni bilimsel çalışmalara cevap vermeye başlamıştır. Türk bilim hayatı, yaklaşık yüz elli yıldan bu yana terim konusuyla ciddi biçimde ilgilenmiş ve bu alanda özellikle Cumhuriyetten sonra 1930 yıllarda Türkçe kimya terminolojisi konusunda çalışmalar yapılıp, komisyonlar kurulup kurumsal ve kişisel anlamda terim sözlükleri yayımlamıştır. Yayımlanan sözlükler, mukayese edildiğinde önemli eksiklikler göze çarpmaktadır. Örneğin, zaman olarak daha sonra yayımlanan sözlükler, bir öncekinin söz varlığını yeterince değerlendirmemektedir. Aynı kavramlar için sözlüklerde farklı terimler verilmektedir. Bu da Türkçede standart bir kimya terminolojisinin oluşmasını engellemektedir. Bu ve buna benzer meseleler çalışmamızda örneklerle ele alınırken bugüne değin Türkiye'de neşredilen bazı kimya terimleri sözlükleri ile son olarak Türk Dil Kurumu tarafindan 2009 yılında yayımlanan Kimya Terimleri Sözlüğü mukayese edilerek üzerinde bilimsel değerlendirmeler yapılacaktır.
\end{abstract}

Anahtar sözcükler: Terim, Kimya, Sözlük, Kimya Terimleri

\begin{abstract}
The words used to define certain concepts relating to a specific art, occupation, or science are called "technical terms". The field of chemistry, formerly called alchemy, has seen very rapid developments, and consequently new words and terms are coined in all languages to reflect in words this rapid progress. As in every specific field, dictionaries and glossaries containing terms that cover the entire field of chemistry have begun to provide guidance for new scientific studies. The Turkish scientific community has meticulously addressed the matter of technical terms for about 150 years, working on the Turkish terms for chemistry, especially after the establishment of the new republic in the 1930's through special commissions and publishing glossaries prepared through institutional and personal effort. However, an analysis of these dictionaries show they contain significant deficiencies. For instance, dictionaries published at a later date fail to adequately cover the lexical items contained in the previous ones, or quite different terms are provided for the same concept, which hinders the formation of a standard chemistry terminology in Turkish. Our study addresses these issues through the use of specific examples, comparing certain dictionaries of chemistry terms published in Turkey with the most recent example, Ferhenga Termen Kimyewi, Kimyasal Terimler Sözlügü, Dictionary of Chemistry Terms, published by the Turkish Language Association in 2009, together with some scientific evaluations.
\end{abstract}

Keywords: Term, Chemistry, Dictionary, Chemistry Terms

\footnotetext{
* Doç. Dr., Akdeniz Üniversitesi, Edebiyat Fakültesi, Türk Dili ve Edebiyatı Bölümü, Antalya. alicin@akdeniz.edu.tr

*** Doç. Dr., Akdeniz Üniversitesi, Fen Fakültesi, Kimya Bölümü, Antalya. gturgut@akdeniz.edu.tr
} 


\section{Giriş}

İnsanlar ve hayvanlar tat, koku, dokunma, görme ve işitmeden oluşan beş kanalla birbirleriyle iletişim kurarlarken (Karaağaç 2013, 9) bir mesleği icra eden insanlar da, terimlerle iletişim kurarlar. Meslek, bilim, sanat ya da zanaat gibi değişik meslek alanlarının kavramlarına özel anlamlar verilerek oluşturulan kelimelerine terim diyoruz. Bir başka ifadeyle belirli bir sahada kullanılan ve özel görevi ve tek anlamı olan kelimelere terim denir (Ahanov 2013, 164). Terim sözü Latince "sınır, son" anlamına gelen terminus kelimesine örnekseme (Karaağaç 2013, 624) yapılarak günümüzde kullandığımız derlemek fiilinin ter->der- fiiline -i-m ekinin getirilmesiyle türetilmiş bir kelimedir (Zülfikar 1991, 20). Türk dili tarihinde kimya kelimesini ilk defa Karahanlı Türkçesi dönemi eserlerinden Kutadgu Bilig'de görüyoruz. Kelime eserde bilig kimya' teg ol neng irklü turur/ukuş̧ ordusı ol neng üglü turur (Arat 1991, 310). "Bilgi kimya gibidir, eşya onun etrafinda toplanır; akl onun sarayıdır, içinde eşya ylğıllı" (Arat 1998, 310) şeklinde geçmektedir.

Kimya kelimesini, Türkçe Sözlükte Arapça kimyā kelimesine dayandırılarak "maddelerin temel yapılarını, birleşimlerini, dönüşümlerini çözümleme, birleşim ve üretim yönlerini inceleyen bilim" olarak tanımlanır (Komisyon 2011, 1443). Türkçenin yakın dönem Osmanlı Türkçesi sözlüklerinde ise kimya kelimesinin Arapçadan dilimize geçtiğini, aslının ise Hellence $\chi \eta \mu \varepsilon i ́ \alpha$ kelimesinden geldiğini ve cisimlerin terkibat ve değişimlerinden bahseden fen şeklinde tanımlanır (Sami 1317, 1228). Kimyager kelimesi ise, kimya bilimiyle ile yani tahlilat ve terkibat-ı kimyeviyye ile uğraşan alim, fenn-i kimya mütehassısl; Güya her şeyi altına tahvil etmek sır ve sanatın bilmek iddiasında bulunan remnal şeklinde açıklanır (Sami 1317, 1228). Şemsettin Sami, simya kelimesini ise Ar. (Hellence $\chi \eta \mu \varepsilon i ́ \alpha)$ kimya ile bir asıldan. Esassız ve mevhum bir ilm-i batıl ki, nice zamanlar sade dilanı işgal etmiştir. "Fr. Magie blance: beyaz büyü" biçiminde açıklar (Sami 1317, 759). Yine yakın dönem sözlüklerinden Lügat-ı Cudi'de kimya kelimesi iksir; bakırı altın veya gümüsse kalbetmek ilm-i batıll; escam-ı uzviyye ve gayr-ı uzviyyenin havās-l asliyyeleri tebeddül etmek şartiyla yekdiğeri üzerinde icra ettikleri tesiratın tabi olduğu kavaninden bahis bir fen biçiminde açıklanırken simya kelimesi ise, "Cifre şebih bir ilm-i garip. Sihir envalndan olduğunu dermeyan edenler de vardir. Batılanı iddia edenler pek de haksız değillerdir" (Parlatır, Aksu \& Tufar 2006, 481) şeklinde açıklanmıştır.

Bilindiği üzere Selçuklu döneminde bilim dili Arapça, edebiyat dilimiz de Farsça olarak kullanılmıştı. Osmanlı'nın ilk döneminde Bağdat, Şam, Semerkant, Kahire gibi dönemin önemli, revaçta olan kültür merkezlerinde yetişen bilim adamları da yine bilim dili olarak Arapçayı seçmiş ve bu dille telif ve tercüme eserler yazmışlardır. 16. yüzyıla kadar yapılan çeviri eserler genel itibariyle fazla olmamakla beraber Arapçadan Osmanlı Türkçesine edebi eserlerin dışında kalan astronomi, coğrafya, tıp, kozmografya alanına ait çevirilerdir. Bu çeviriler çeşitli biçimlerle 18. yüzyıla kadar devam etmiştir. 18. yüzyıldan itibaren Osmanlı Devleti'nin Batıyla ilişkisi her anlamda artmakla birlikte özellikle ekonomi, askerlik ve modern teknoloji alanında sıkı bir ilişkinin olduğunu söylemek mümkündür. Batılılaşma, modernleşme adına Avrupa ile olan bu ilişki, kendini her alanda gösterirken eğitim alanında göstermemesi mümkün değildi. İlk olarak mühendislik ve askeri teknik konuları ele alan ilgili kitapların Avrupa kitaplarından çevrilmesiyle başlayan bu hareket, daha sonra kendisi tıp alanında da göstermiş̧ir. 1817- 1856 yılları arasında tıp alanında bir takım kitaplar yayımlanmakla birlikte Mekteb-i Tibbiye-yi Şahane'de öğretim dilinin Fransızca olması sebebiyle Türkçe ders kitaplarının basılması da gecikmiştir. 19. yüzyılda devletin yaptığı en önemli işlerden birisi, modern eğitim kurumlarında okutulacak ders kitaplarının hazırlanması ve Avrupada yayımlanan bilim kitaplarının tercüme edilmesi görevini yürütecek Encümen-i Daniş adlı bir kurumun oluşturulmasıdır. Ancak bu kurul hedeflenen beklentiyi karşılayamamış ve 1862 yılında dağılmıştır. Tercüme işleri de kişilerin özel gayretine bırakılmıştır. Bu dönemde Batı bilim dünyasının kitapları tercüme edilirken terimler çoğunlukla çevrilen dilden olduğu gibi alınırken zaman zaman da Arapça köklerden kelimeler ya da terimler türetilmiştir. Bu dönemde Arapça köklerden kamer (mukmir), şems (müşemmes), kevkep (mükevkeb) gibi kelimelerin türetildiğini biliyoruz (Levend 1972, 182). 
Modern kimyanın kurucusu Cabir bin Hayyan'dır (Kâhya 1995, 5). Osmanlıda modern anlamda ilk kimya çalışmaları Bursalı Ömer Şifai'nin Tıbb-ı Cedid-i Kimyai (Kâhya 1993, 172) adlı kitabıyla başlasa da asıl kimya biliminin ve terminolojisinin oluşmaya başladığı zaman ise 19 . yüzyıldır. $\mathrm{Bu}$ dönemde Avrupa kimya kitaplarından tercüme edilerek yayımlanmış birkaç kitap bulunmaktadır (Günergun 2003, 7). Bunlardan birisi Yahya Naci'nin 1809 y1lında II. Mahmut'un emriyle tercüme ettiği ve kimya ile ilgili olarak havanın özellikleri, yanma, yakma, kimyasal elementler, sindirim, dolaşım vb. gibi konuların anlatıldığı Risale fi-hikmet-i taibiiye adlı eseridir (Günergun 2003,9). İkinci eser, İshak Efendi'nin Мecmua-yı Ulum-i Riyâziye adlı eserin son cildinde yer alan ve elementlerin, asitlerin, bitkisel ve hayvansal maddelerin analizinin anlatıldığ 129 sayfalık bir eserdir (Günergun 2003, 8). Üçüncü eser, 1835 yılında İngiltere'ye gönderilen daha sonra Fransa'ya geçerek öğrenimini tamamlayan ve Mekteb-i Harbiye'de kimya dersleri veren Kimyager Derviş Paşa'nın yazdığı Usul-i Kimya adlı çalışmadır (Günergun 2003,8). Derviş Paşa, Türkçenin Avrupa dillerine benzemediği için Batıdaki kimya terimlerinin Türkçe kitaplarda kullanılmasının uygun olmadığını, kendisinin de mümkün mertebe Türkçe terimleri tercih edeceğini, ancak Türkçelerinin bulunmadığı durumlarda da elementlerin isimlerini Fransızca okuyuşa uygun olarak yazacağını belirtir (Günergun 2003, 9). Bu alanda yazılmış diğer bir eser de Kırımlı Aziz'in Kimya-yı Tıbbî adını verdiği anorganik kimya ders kitabıdır (Günergun 2003, 9). Kırımlı, ayrıca kimyasal bileşikleri lisan-ı Türkî ile adlandırmak için kuralları tespit etmiş, Fransızca ve Türkçe kimya terminolojinin birbirlerine nasıl dönüştürüldügünü açıklamıştır (Günergun 2003, 9). Kırımlı Aziz'in kullandığı kimya terimleri Arapça kaynaklı olmasına rağmen sstılahat-ı Türkî'den bahsetmesi oldukça dikkat çekicidir (Günergun 2003, 9).

19. yüzyılda kimyada kullanılan azot, oksijen ve hidrojen elementlerinin Osmanlı Türkçesindeki türetilmiş biçimler şu şekildedir.

\begin{tabular}{|c|c|c|}
\hline \multirow[t]{3}{*}{ azot: } & hava-yı mematî & ölüme sebep olan (gaz) \\
\hline & hava-yı lä hayate lehu & hayat vermeyen hava \\
\hline & hava-yı lā hayate lekin & hayat vermeyen/hayatı olmayan hava \\
\hline \multicolumn{2}{|c|}{ oksijen: hava-yı hayatî } & hayat veren hava \\
\hline \multicolumn{2}{|r|}{ müvellidü'l-humuza } & asit/oksit doğuran \\
\hline \multicolumn{2}{|r|}{ hava-yı müvellidü'l-humuzat } & asit/oksit doğuranın aslı \\
\hline \multicolumn{2}{|c|}{ hidrojen:müvellidü'l-ma } & su doğuran \\
\hline & hava-yı muharrak & ateş alabilen gaz \\
\hline & hava-yı müşstail & alev alabilen gaz \\
\hline & hava-yı muharrakın üssü & ateş alan gazın esası (Günergun 2003, 9). \\
\hline
\end{tabular}

Söz konusu Osmanlıca terimlerden azot elementi için kullanılanlar kabul görmemişken hidrojen için kullanılan müvellidü'l-ma ve oksijen için kullanılan müvellidü'l-humuza terimleri 1928 yılına kadar kullanılmıştır (Günergun 2003,13). Bu arada I. Dünya Savaşı sırasında 1915'te Darülfünun'u sslah etmek amacıyla Almanya'dan 20 civarında bilim adamı davet edilmiştir. Dr. Fritz Arnd, Gustav Fester ve Kurt Hoesch (Dölen 2015,10-11) fen fakültesi kimya-yı gayr-ı uzvî (Anaorganik kimya) bölümünde görev yapan yabancı bilim adamlarındandır. 1916 yılında Dr. Fritz Arnd'ın yardımcılığına atanan Fazlı Faik Yeğ̈̈l'ün gerek hocası Fritz Arnd'ın eserlerinden gerekse diğer Alman bilim adamlarından yaptığ çevirilerle (Dölen 2015,13-15) Türk kimya bilimine katkıları büyüktür.

Günümüzde kullandığımız organik kimya terimi için Osmanlı Türkçesinde kimyâ-yı uzvî, inorganik kimya terimi için kimyâ-yı gayr-ı uzvî, biyokimya terimi için kimyâ-yı hayatî, fizikokimya için fizikî kimya, analitik kimya için ise kimyâ-yı tahlilî terimleri kullanılmaktaydı.

Cumhuriyetle birlikte her alanda kendini gösteren değişim, dönüşüm ve ilerleme kendisi öncelikle 
dil alanında gösterirken bunun bilim dünyasına yansıması özellikle terimlerle olmuştur. Türk Tarih ve Dil Kurumu'nun kuruluşundan sonra Atatürk, Türk biliminin ilerleyebilmesi için terimler üzerine yoğunlaşmış hatta geometri terimleri üzerinde çalışarak y1llardır çoğu Arapça kökenli biçimiyle kullanılan terimlerin yerine üçgen, dörtgen, açı gibi Türkçe terimler türetmiştir. (Tan 2001, 48) Cumhuriyetten sonra kimya terimleri, bir bütün olarak Türk Dil Kurumu tarafindan ilk kez 1937 yılında ele alınmıştır (Zülfikar 2006, 328). Komisyon başkanı Akil Muhtar Özmen 1938 yılında Tedavi Kliniği ve Laboratuarı dergisinde çoğunluğunun batı kökenli olan terimlerden oluşan bir çalışma sunar. Bunlardan birkaçı şunlardır: özey /qualitatif; çokey/quantitatif; çözey /solution; sıvlk /liquide (Zülfikar 2006, 328). İstanbul Üniversitesi Fen Fakültesi Kimya bölümü hocalarından Tarık Artel'in 1935 y1lında çıkan Türkçe Kimya Nomenclaturu Nasıl Olmalıdır adlı çalışması, yayımlandığı yıllarda ilgi uyandırmakla birlikte, batı dillerinden $x, q, w$ harflerinin Türk alfabesine alınması düşüncesi ve batıda kullanılan uluslararası nitelik kazanmış sözcüklerin Türk kimya terminolojisine, kökleriyle birlikte muhafaza edilerek kazandırılması fikri, kabul görmemiştir (Elmacı 20015, 32). Cumhuriyetten sonra terimlerle ilgili yapılan önemli çalışmalardan birisi de, Milli Eğitim Bakanlığı tarafından yayımlanan Türkçe Terimler Cep Kılavuzu (Astronomi, Botanik, Coğrafya, Fizik, Jeoloji, Kimya, Matematik, Zooloji) adlı eserdir. Eser her ne kadar orta öğretim öğrencilerinin ihtiyaçlarını bir noktaya kadar karşılasa da, Yüksek Öğretim terimlerini karşılamaya yetmemiştir. Bu alanda yayımlanmış diğer bir eser de, Kültür Bakanlığı tarafindan 1937 yılında yayımlanan İlk ve Orta Öğretim Kimya Terimleri adlı çalışmadır. Fen bilimleri içerisinde yabancı terminolojiyi içerisinde en fazla bulunduran bilim dalı kimyadır. 1960 yılında terimlerin önemine binaen uluslararası birliğin sağlanması adına Uluslararası Ağırlık ve Ölçüler Genel Konferansı düzenlenmiş ve bunun sonucunda Uluslararası Birim Sistemi (Système international d'unités) kısaca SI ile gösterilen birimler sistemi kabul edilmiş ve ülkemizde de 1989 yılında 3516 sayılı kanunla yürürlüğe girmiştir (Somer \& Yaşar 2009, 7). Bu durum da kimyada yabancı terminolojiyi arttıran etkenlerden biri olmuştur. Çalışmamızla ilgili olarak incelemeye dahil etmesek de, Oktay Sinanoğlu'nun Fiziksel Kimya Terimleri Sözlüğü adlı eserini zikretmek gerekir (Sinanoğlu 1978).

Kimya bilimiyle ilgili bu açıklamalarımızdan sonra ilk olarak inceleyeceğimiz eser Türk Dil Kurumu tarafından hazırlanan Kimya Terimleri Sözlüğ̈̈ adlı çalışmadır (Üneri, Kuleli \& Gürel 1981). $\mathrm{Bu}$ çalışma iki yüz sayfadan oluşan yaklaşık 1250 kelimelik bir terim sözlüğüdür. Çalışmanın sözlük kısmından sonra Eski Terimler Dizini başlığı altında yaklaşık 1222, İngilizce, Almanca ve Fransızca Dizin başlıkları altında da yine yaklaşık 1250 kelimenin dizini verilmiştir. Çalışmada madde başı olarak verilen terimin öncelikle eskiden kullanılıyorsa eski terim biçimiyle anlamı, sonra da Almanca, Fransızca ve İngilizce karş11ıkları verilmiştir. Örneğin; ağ: (eski terim: şebeke; Alm. netz; Fr. branchement; Ing. network) İplik, tel boru vb. örülmüş bir yap türü. Söz konusu çalışmada yabancı dillerden gelen terimler için Türkçe karşılıklar bulma gayreti açıkça görülür. Özdek: (eski terim: madde; Alm. Stoff; Fr. matiére; İng. matter)İnsan bilincinden bă̆ımsız olarak somut biçimlerde var olan tüm nensneler. Örüt: (eski terim: billur, kristal; Alm. kristall; Fr. cristal; Ing. crystal) Atom ve molekülleri... Söz konusu çalışmayla ilgili olarak Türkçe karşıllklarıyla dikkat çekmek istediğimiz ve kimya terimi olamayacağını düşündüğümüz bazı kelimeler şunlardır: (Alfabetik dizinde italik olarak gösterilen terimler, üç sözlükte de ortak olarak geçtiğini göstermek için kullanılmıştır)

$\begin{array}{llll}\text { akaryakıt } & \text { aygıtla çözümleme } & \text { bölüşüm } & \text { donmä̈nler } \\ \text { akım } & \text { bağıntı } & \text { çanak } & \text { dönemli } \\ \text { akım ölçer } & \text { bağışıklık } & \text { çıtıtı } & \text { dural } \\ \text { akım potansiyeli } & \text { bardak } & \text { çizelge } & \text { duyar tartaç } \\ \text { akkor } & \text { basınç } & \text { çömlek } & \text { duyarlık } \\ \text { arıtım yeri } & \text { belirleme } & \text { diyaliz } & \text { duyulur } 1 \text { s1 } \\ \text { aritmetik ortalama } & \text { biçimsiz } & \text { dizil bağlama } & \text { edilginlik } \\ \text { aşındırma } & \text { boşluk } & \text { doğa } & \text { emeç } \\ \text { aygıt } & \text { bölümleme } & \text { donatım } & \text { erke }\end{array}$




$\begin{array}{llll}\text { girdi } & \text { iç basınç ölçer } & \text { kirletici } & \text { özdevinimsel } \\ \text { gizilerke } & \text { jenaratör } & \text { kolan } & \text { patlataç } \\ \text { ham özdek } & \text { karışma } & \text { kon } & \text { sicaklıölçer } \\ \text { havan } & \text { karştırıc1 } & \text { korunç } & \text { simge } \\ \text { havayuvar } & \text { katık } & \text { kuruma } & \text { tartaç } \\ \text { hız bilim } & \text { katı̧ıłklık } & \text { minil çözümleme } & \text { uyutucu } \\ \text { hız yöneyi } & \text { kavurma } & \text { minilgözler } & \\ \text { 1ş1 bireşim } & \text { kaynak } & \text { nitelik } & \\ 1 \text { 1̧̧1 elektrik } & \text { kirlenme } & \text { ölçün sapma } & \end{array}$

Türk Dil Kurumu'nun 1981 y1lında yayımlanan terimler sözlügünün en önemli hususiyetlerinden birisi, Batıdan dilimize giren ya da girmeye çalışan o günkü kimya terimlerine Türkçe karşılık bulma çabasıdır. Tartaç "terazi", duyar tartaç "hassas terazi", emeç "aspiratör", özdevinimsel "otomatik", minilgözler "mikroskop"; ham özdek "ham madde", korunç "sigorta", erke "enerji", gizilerke "gizli enerji"...vb. Terim sözlügünde yer alan çömlek, çanak, bardak, doğa, havan... gibi kelimeler birer kimya terimi değildir.

İkinci çalışma ise, yedi ayrı üniversitedeki analitik, organik, anorganik, fizikokimya, biokimya anabilim dallarının öğretim üyelerinin katkılarıyla hazırlanan ve Türk Dil Kurumu tarafından 2009 yılında basılan Kimya Terimleri Sözlüğü (Güler \& Yaşar 2009) adlı çalışmadır. Bu çalışma, Kimya alanında çalışan bilim adamlarınca hazırlanmış çalışma olup 477 sayfa ve yaklaşık 6000 bin civarında kelimeden oluşmaktadır. Eser, sözlük ve Almanca-Türkçe, Fransızca-Türkçe ve İngilizce-Türkçe dizinden oluşmaktadır.

Çalışmada her ne kadar Kimya Terimleri Sözlü̆ğü hazırlanırken Türkçe kelimelerin esas alındığı, her terim için Almanca, Fransızca, Ingilizce ve Osmanlı Türkçesi karşlıkları bulunmaya çalışıldı (Güler \& Yaşar 2009, 7) şeklinde bir ifade kullanılsa da, terimlerin Osmanlı Türkçesinde geçen biçimlerine yer verilmemiştir. Bir bilim alanına ait ideal bir terim sözlüğü, bugün için kullanılmasa da, düne ait terim sözvarlığını muhafaza etmelidir, düne ait literatüre yer vermelidir. Çünkü bilimde süreklilik esastır.

Türk Dil Kurumu'nun 1981 yılında basılan terim sözlügünde yağlara yer verilmezken 2009 yılında

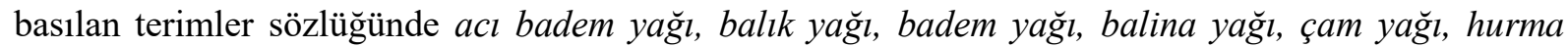
$y a \breve{g} l v b$. gibi yağlar birer terim olarak kabul edilmiştir. Oysa yağın kendisi bir maddedir, ancak bir kimya terimi değildir. Dolayısıyla bu tür kelimelerin terim sözlüğünde bulunmaması gerekir ya da bütün yağların yer alması gerekir. Keza zeytin yağı kelimesi de yine böyledir. Muhtemelen sözlükte geçen balina yă̆ı ve benzeri kelimeler, taranan eserlerde yer aldığ 1 için olduğu gibi, herhangi bir süzgeçten geçirilmeksizin o eserlerden aktarılmıştır.

Eserde Henry H. Joseph, Hofmann August Wilhelm, Hopkins Sir Friedrik Gowland gibi bazı bilim adamlarının adları geçmektedir. Bilim adamlarının adları terim sözlüklerinde değil, kimya sözlüklerinde yer almalıdır.

1981 y1lında basılan terim sözlüğünde donmaönler terimi, antifriz terimi karşıllı̆ı için türetilmiş bir kelimedir. 2009 yılında basılan terim sözlüğü, donmaönler terimine hiç yer vermeyip sadece antifriz kelimesini madde başı olarak alırken 2005 yılında basılan terim sözlüğü ise, donma önleyici ve antifreeze terimlerini kullanmayı tercih etmiştir.

Çalışmada bu tür kelimelerin yanı sıra sosyal hayatta, diğer bilim dallarında da rahatlıkla kullanılan bazı kelimeler birer kimya terimi gibi kullanılmıştır. Bu kelimelerin birer kimya terimi olup olmadıkları tartışmalıdır. zaman, uzay, uzunluk, sıcaklık, şeker kamışı, şeker pancarl, kilo, litre, metre, kan, kalp pili vb. (* işaretiyle gösterilen kelimeler yağları vurgulamak için kullanılmıştır) 


\begin{tabular}{|c|c|}
\hline ac1 badem yağ $1 *$ & iktulin \\
\hline adrenalin & iletin \\
\hline akım & immunoterapi \\
\hline akkor & immünoloji \\
\hline$a k \ddot{u}$ & imparator yeşimi \\
\hline akümülator & inç \\
\hline altigen & infilak etmek \\
\hline aşındırma & ispermeçet balinas 1 \\
\hline aydinlaticı & ispermeçet yağı* \\
\hline aydinlatmak & izlanda taş1 \\
\hline badem yağ $1 *$ & izlanda yosunu \\
\hline bağışıklık & jaboti yağ $1 *$ \\
\hline balık yăğ $*$ & jakutinga \\
\hline balina yağ ${ }^{\prime} *$ & jalap \\
\hline bar & jalapoit \\
\hline barometre & jambu \\
\hline basınç & jambul \\
\hline batarya & james çayı \\
\hline beriberi & japon verniği \\
\hline beton & jaw yağ $1 *$ \\
\hline beygir gücü & jeodinamik \\
\hline bilgisayar & jig \\
\hline donanımı & joule \\
\hline blender & joule eşdeğeri \\
\hline bobin & joule etkisi \\
\hline bohça & juniper \\
\hline çam yağ $1 *$ & juniper meyvesi \\
\hline çamur & juniper tohum yağı* \\
\hline çekiçli kırııı & kăglt \\
\hline çıktı & kaiser \\
\hline çizelge & kaladana \\
\hline$c ̧ o ̈ p$ & kalamia \\
\hline defne yaprağ 1 & kalikret \\
\hline yağ $1 *$ & kalite güvencesi \\
\hline değirmen & kalori \\
\hline deneme-yanılma & kalp pili \\
\hline diyaliz & kamala \\
\hline $\operatorname{dog} a$ & kan \\
\hline doğa yasast & kan albümini \\
\hline doğal ürün & kan hücresi \\
\hline don yağ1* & kanamisin \\
\hline duyarlık & kandela \\
\hline ekoloji & kanebain \\
\hline fenoloji & kar karyokines \\
\hline hektar & karışabilir \\
\hline hekto & karışma \\
\hline hemotoloji & karistırıcı \\
\hline henry & kasidve yağ $1 *$ \\
\hline henry h. joseph & katsayl \\
\hline histoloji & kauri \\
\hline hopkins sir friedrick & kava \\
\hline hurma yağı* & kavanoz \\
\hline
\end{tabular}

\begin{tabular}{|c|c|}
\hline kavatel yağ $1 *$ & miligram \\
\hline klvam & mililitre \\
\hline kilo & misk otu \\
\hline kilogram metre & miyosin \\
\hline kilohertz & mukavemet \\
\hline kilokalori & mutlak hata \\
\hline kilowatt & nanogen \\
\hline kirlenme & nanometre \\
\hline kitol & narkotik \\
\hline kittol lifi & nokta \\
\hline klasik fizik & nomograf \\
\hline knot & odak \\
\hline kobra & odun \\
\hline koku & ohm \\
\hline kolomal & ohm kanunu \\
\hline kolza tohum yağ1* & olasılik hesab1 \\
\hline komof & opak \\
\hline kompral & optik \\
\hline konglutinin & optik a $\breve{g}$ \\
\hline konkav & optimum \\
\hline korona & orant1li hata \\
\hline kozmetik & ordinat \\
\hline kraft kağıd 1 & organ nakli \\
\hline kripto & ortalama \\
\hline kulon & ortam \\
\hline kurum & ortanca \\
\hline kusamba & osilograf \\
\hline labiate & özsu \\
\hline ladanum* & paketleme \\
\hline laetril & palinoloji \\
\hline lana & palmin * \\
\hline lentikular & panadol \\
\hline leptoloji & pankreatin \\
\hline likör & paralel \\
\hline likra & parasitisit \\
\hline limanol & parathormon \\
\hline linen & paratroit hormonu \\
\hline lint & parazit \\
\hline litre & parkinson hastalığı \\
\hline logaritma & pasif aşılama \\
\hline lucto bacillus & paskal \\
\hline lüks & pasteur louis \\
\hline lümen & pastörize edilmiş süt \\
\hline mantar & pataloji \\
\hline mavi & patalojik \\
\hline maydanoz & patent \\
\hline metalurji & patojen \\
\hline metre & patojenik \\
\hline mikron altı & penisilin \\
\hline mikrop & pilot tesis \\
\hline mikroskop & prizma \\
\hline mil & regresyon analizi \\
\hline
\end{tabular}




$\begin{array}{llll}\text { reoloji } & \text { sicaklık } & \text { somatik mutasyon } & \text { ufalama } \\ \text { reosta } & \text { siğa } & \text { soya fasulyesi } & \text { uyutucu } \\ \text { saat yönü } & \text { sizma } & \text { soya fasulyesi yağı* } & \text { uzay } \\ \text { saatin ters yönü } & \text { siemens } & \text { su küre } & \text { uzunluk } \\ \text { sabit hata } & \text { silaj } & \text { sürat } & \text { üstel } \\ \text { sabun köpüğü } & \text { sileks } & \text { şeker kamışı } & \text { üzüm çekirdeği } \\ \text { safra asitleri } & \text { simetri } & \text { şeker pancarı } & \text { yağı* } \\ \text { sağlığa zararlı } & \text { simge } & \text { şerbetçi otu } & \text { valinomisin } \\ \text { salınım } & \text { sinerji } & \text { şerbetçi otu yă̆ı* } & \text { viomisin } \\ \text { santigram } & \text { sis } & \text { tamamlayan } & \text { virüs } \\ \text { sapan değer } & \text { sis odası } & \text { taşs } & \text { volkan gazı } \\ \text { sapma } & \text { sisleştirici } & \text { taşıma } & \text { yatay } \\ \text { sarı vernik } & \text { sistematik hata } & \text { terazi } & \text { yerçekimi } \\ \text { sekiz yüzlü } & \text { sistemik } & \text { termostat } & \text { zaman } \\ \text { sentetik } & \text { soğuk } & \text { ticari marka } & \text { zehir } \\ \text { seramik } & \text { soğuma } & \text { tonka fasülyesi } & \text { zeytinyağı* } \\ \text { seylan tarçını } & \text { somatik hücre } & \text { toprak } & \end{array}$

Üçüncü olarak inceleyeceğimiz eser, ilk baskısı 1998'de olan, elimizdeki bask1 ise genişletilmiş üçüncü baskı olan ve 2005 yılında basılan Kimya ve Kimya Mühendisliği İngilizce-Türkçe; TürkçeIngilizce Terimler Sözlüğü adını taşımaktadır (Berkem \& Gültekin 2005). Eser 440 sayfadan ve yaklaşık 9500 madde başı kelimeden oluşmaktadır. Her ne kadar eser, Kimya ve Kimya Mühendisliği Ingilizce-Türkçe; Türkçe- Ingilizce Terimler Sözlügü adını taşısa da sanki Ingilizce-Türkçe; TürkçeIngilizce teknik bir sözlük gibi yazılmıştır. Çalışma kimya ile ilgili 20 civarında kaynak eser taranarak terimler ve çok kullanılan kalıplar ortaya çıkarılıp bir araya getirilerek hazırlanmış (Berkem \& Gültekin 2005, 2) bir sözlüktür. Dolayısıyla çalışmaya belki de Kimyada Kalıp Iffadeler ve Terimler adı verilmiş olsaydı daha iyi olurdu. Söz konusu çalışmada akademi, akademisyen, akıl hocası, abone, anormal, araştırma enstitüsü... gibi daha birçok kelime terim olmaktan çok uzaktır. Söz konusu eserde kimya terimi olarak değerlendirilemeyecek 1800 civarında kelime tespit edilmiştir. Bunlardan bazılarını aşağıda zikretmek istiyoruz.

$\begin{array}{llll}\text { abone } & \text { akaryakıt } & \text { amortisör } & \text { asimilasyon } \\ \text { acayip } & \text { akciğere ait } & \text { amper } & \text { astigmatlık } \\ \text { acenta } & \text { akılsızca } & \text { ampermetre } & \text { aşağı } \\ \text { acı } & \text { akım } & \text { ampul } & \text { aşındırma } \\ \text { acil durum } & \text { akım ölçer } & \text { anormal } & \text { aşırı } \\ \text { acil hat } & \text { akıntı } & \text { anormallik } & \text { aydınlatmak } \\ \text { açı } & \text { akıtmak } & \text { anestezik } & \text { aygıt } \\ \text { açığa vurma } & \text { akkor } & \text { anten } & \text { baca } \\ \text { açıölçer } & \text { akma } & \text { antet } & \text { bağıntı } \\ \text { açılsal } & \text { akustik } & \text { apaçı } & \text { bağış } \\ \text { açısallık } & \text { akü } & \text { arıtma yeri } & \text { bağışıklık } \\ \text { açmak } & \text { akümülator } & \text { arıza } & \text { bahar } \\ \text { açmaz } & \text { alaca } & \text { arızaya dayanıklı } & \text { bahsetmek } \\ \text { adanmış } & \text { alerji yapıcılar } & \text { aritmetik ortalama } & \text { bakım } \\ \text { adrenalin } & \text { alet } & \text { arka plan } & \text { bakiye } \\ \text { adres } & \text { alev } & \text { arsa } & \text { balıkyağı } \\ \text { afiş } & \text { algoritma } & \text { artma miktarı } & \text { barındırmak } \\ \text { akademi } & \text { amblem } & \text { arz-talep } & \text { barometre } \\ \text { akademisyen } & \text { ameliyat } & \text { asal sayı } & \text { basılı kopya } \\ \text { akan } & \text { amortisman } & \text { asansör } & \text { basınç }\end{array}$




\begin{tabular}{|c|c|c|c|}
\hline basit & çekiç & disket & hardal yağ $1 *$ \\
\hline batarya & çekişme & disket yuvası & harf \\
\hline batırmak & çekmece & diyaliz & havacılik \\
\hline belirgin & çember grafik & dizüstü bilgisayar & havan \\
\hline belirleme & çeneli kepçe & $\operatorname{dog} a$ & havlu \\
\hline bellek havuzu & çentik & doğa yasası & hayvan derisi \\
\hline besi & çevirici dili & doğal afet & hazır giyim \\
\hline beton & çevirmen & doğru & hint keneviri \\
\hline beyaz & çevre bilimi & dolap & hint yăğ ${ }^{*}$ \\
\hline bez parçası & çift sayı & dolgu efekti & hisse \\
\hline biçak & çift tıklama & dolu & histerisiz \\
\hline birakmak & çiğit yăğ ${ }^{*}$ & domuz & hoparlör \\
\hline biçimsiz & çivilemek & donatmak & huy \\
\hline biçmek & çizelge & donmayı önleyici & icat etmek \\
\hline biyoloji & çizelgelemek & donuk & idare etmek \\
\hline blucin & çizgi & dosya & iklim \\
\hline bobin & çizgi kusurları & dosyalamak & iklimleme \\
\hline boğaz & çok dilli & döküntü & imzalamak \\
\hline boğma & çorap & dönemli & inç \\
\hline boş belge & çölleşme & döşemek & ingilizce \\
\hline boş bellek & çömlekçilik & drenaj & iniş \\
\hline boşluk & $c ̧ o ̈ p$ & duyarlık & insan gücü \\
\hline boylam & çöp kutusu & ebediyen & iplikhane \\
\hline böcek & çöplük & edebiyat & ipucu \\
\hline bölümleme & çözüm & ehliyetsiz & iskelet \\
\hline bulaşıcı & daktilo & emeç & istatistik bilimi \\
\hline bulmak & dar boğaz & emin & iş kuyruğu \\
\hline bünye & davlumbaz & ergenlik & işçi \\
\hline camc1 & defter & erişim kodu & ithalat \\
\hline camcilık & değinmek & eşarp & izci \\
\hline canlı & değirmen & eşofman & jul \\
\hline cansiz & değiş tokuş & eşya & kadife \\
\hline cd-rom sürücü & delgi & faks & $k a \breve{g} l t$ \\
\hline cebir & demirbaş & faks makinesi & kalın \\
\hline cep klavuzu & demode & fare & kalın yazı tipi \\
\hline cephane & deneme-yantlma & fatura & kalite güvence \\
\hline cetvel & denetlemek & firtına & kalori \\
\hline civata & deyim & fiat teklifi & kamu \\
\hline ciddi & $\mathrm{d}_{1}$ Ş & fitilli kadife & kanaviçe \\
\hline cilt & dış bellek & fiyat & kangal \\
\hline ciltçi & dil bilgisi & gemi & kaos \\
\hline çamaşırhane & dil özelliği & genç & karakter biçimi \\
\hline çamur & dindirmek & gençlik & karışabilir \\
\hline çanak & dingil & kart1 & karlştırıcı \\
\hline çanak-çömlek & dinlenme & girdap & karma bilgisayar \\
\hline çap & $\operatorname{dip}$ & girdi & karma karış1k \\
\hline çare & dipnot & günü geçmiș & katalog \\
\hline çatlak & disk sürücü & haberleşme & katiyen \\
\hline
\end{tabular}




\begin{tabular}{|c|c|c|c|}
\hline katsayl & madencilik & oto tamircisi & toka \\
\hline kavanoz & mantar & otobüs & topak \\
\hline kavram & masaüstü & oturmak & topoloji \\
\hline kavşak & matkap & oturum & toprak \\
\hline kaydetme & $m a v i$ & oval & torba \\
\hline kayit & mayın & oylum & total \\
\hline kayit defteri & mayo & önek & uçak \\
\hline kaynak & meşrubat & önemli & ufalama \\
\hline kaynak belge & metalurji & öngörü & uğraş \\
\hline kıvamlılık & metin & ön izleme & ulaşmak \\
\hline k1vilcim & metin alanı & örs & uysallık \\
\hline k1vrik & metin dosyas 1 & öte & иуитиси \\
\hline k1yafet & metin özelliği & ötesinde & uzak \\
\hline kilim & metre & özdevinimsel & uzakl1k \\
\hline kilitli dosya & metrik & paketleme & uzama \\
\hline kimlik & metrik sistem & paklama & uzay \\
\hline kiriş & meyil & palto & uzman \\
\hline kirlenme & meyve suyu & panel & uzun \\
\hline kirletici & mezun olmak & para & uzunluk \\
\hline kirli çamaşır & misir & paralel & ücret \\
\hline kişisel & misir unu & pastil & üst satır \\
\hline klasör & mikrop & patent & üstel \\
\hline klavye & mimarlık & patron & ütü \\
\hline klima & miyop & pergel & ütülemek \\
\hline klimalı & mobil & pipo & virgül \\
\hline kod & nicem & pirinç & virüs \\
\hline koklamak & nispet & pirit & yer işareti \\
\hline koku & nitelemek & postalamak & yeşil \\
\hline kolay erişim & nitelik & prizma & yinelemek \\
\hline komplike & noktalı çizgi & pusula & zaman \\
\hline kozmetik & not & rakip & zehir \\
\hline köken & not defteri & repertuar & zeka \\
\hline kömür ambarı & not etmek & tamamlayan & 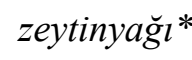 \\
\hline kriko & objektif & taş & zimpara \\
\hline kroki & oda & taşıt & \\
\hline kullanış & odun & tatl1 & \\
\hline kulon & ohm & teker & \\
\hline kupkuru & ohm kanunu & tepsi & \\
\hline kurgu & olumsuz & terazi & \\
\hline kurum & onay işareti & terbiye & \\
\hline kuş bakışı & ondalık & terleme & \\
\hline kütüphane & optimum & termostat & \\
\hline lenf bezi & ortakl1k & terzi & \\
\hline leş & ortalama & tez & \\
\hline lezzet & ortalı & tıp bilmi & \\
\hline lisans & ortam & ticaret & \\
\hline $\log 0$ & ortanca & ticari marka & \\
\hline maden & osilograf & tiryaki & \\
\hline
\end{tabular}




\section{Sonuc}

19. yüzyılda Avrupa biliminin etkisiyle Arapça ve Farsça köklerden türetilerek bir müddet kullanılan uzun, tamlamalı eski kimya terminolojisi yerini Cumhuriyetle birlikte sade ve anlaşılır bir terminolojiye bırakmıştır. Cumhuriyetin ilk yıllarındaki bu bilinçle birlikte, bir müddet Türkçe karşılığı olan yabancı terimler kullanılmamıştır. Ancak bu dönemden sonra, yeni türetilen kelimelerin bir kısmının tutulmuş olmasına rağmen yeni ihtiyaçları karşılamak için yeter derecede terim üretilememesi başarıyı sekteye uğratmıştır. İlerleyen yıllarda terimlerin Türkçeleştirilmesi bilincinin daha da zayıflaması, terim tanımlamaların Batı tanımlarını esas alması, terimlerin büyük bir kısmının maddeyi yeterince açıklayamaması ve dildeki gelişmelere paralel olarak Batı kökenli kimya terminolojisi, bilim adamlarımız arasında giderek yayılmış ve sonuçta Türk kimya terminolojisine, Türkçe kökenli terimlerden oluşan bir terminolojisi yerine Latin kökenli bir terminoloji hâkim olmuştur. Üzerinde inceleme yaptığımız üç terim sözlüğünün içerisinde kimya biliminin kavramlarını en iyi şekilde açıklayan sözlük Türk Dil Kurumu tarafından 1981 yılında yayımlanan sözlüktür. İncelenen sözlüklerde önemli eksiklikler tespit edilmiştir. Kimya alanı için terim olarak kullanılmayan bazı kelimelere sözlüklerde terim olarak yer verildiği (Zeytin yă̆ı, defne yapră̆l yă̆l, hurma yağl vb.) göze çarpmaktadır. Daha sonra yayımlanan sözlükler, bir önceki zamanda yayımlanan sözlüklerin söz varlığını ya görmezden gelmiş ya da yeterince değerlendirememiştir. Türkçede standart bir kimya terminolojisinin oluşabilmesi için Türk kimya bilimcilerine düşen önemli görev, her bilim dalının (organik, analitik vb.) terimlerini ortaya koymak ve onları Türkçenin kurallarına göre, anlaşılır biçimde tanımlamaktır. $\mathrm{Bu}$ tarz çalışmalar hem üzerinde çalışılan bilim alanından hem de dilbilim alanından uzmanların katılımıyla, disiplinler arası bir çalışmanın neticesinde ortaya çıkarılırsa sağlam, kalıcı ve bilimsel bir çalışma olabilir. 


\section{KAYNAKÇA}

Ahanov K. (2013). Dil Bilimin Esaslart. Ankara 2013.

Arat R. R. (1991). Kutadgu Bilig (Metin). Ankara 1991.

Arat R. R. (1998). Kutadgu Bilig (Çeviri). Ankara 1998.

Berkem A. R. \& Gültekin S. (2005). Kimya ve Kimya Mühendisliği Terimler Sözlüğü. Ankara 2005.

Dölen E. (2015). “Ölümünün 50. Y1lında Veteriner Kimyager Ord. Prof. Fazlı Faik Yeğül (1882-1965)”. Osmanlı Bilimi Araştırmaları XVII/1 (2015) 10-11.

Elmaci İ. (2015). “Tarık Ertel ve Türkçe Kimya Terminolojisi”. Erdem Dergisi 68 (2015) 23-33.

Günergun F. (2003). “Ondokuzuncu Yüzyıl Türkiye'sinde Kimya'da Adlandırma”. Osmanlı Bilimi Araştırmalart V/1 (2003) 1-33.

Kâhya E. (1993). “Ömer Şifâ”. Osmanlı Tarihi Araştırma ve Uygulama Merkezi Dergisi 4 (1993) 171195.

Kâhya E. (1995). Modern Kimyanın Kurucusu Cabir b. Hayyan. Ankara 1995.

Karaağaç G. (2013). Dil Bilimi Terimleri Sözlüğ̈̈. Ankara 2013.

Karal Z. E. (2001). Bilim Kültür ve Öğretim Dili Olarak Türkçe. Ankara 2001.

Levend A. S. (1972). Türk Dilinde Sadeleşme Evreleri. Ankara 1972.

Parlatır İ., Aksu B. \& Tufar N. (2006). Lügat-l Cûdî. Ankara 2006.

Sami Ş. (1317). Kamus-ı Türkî. İstanbul 1317.

Sinanoğlu O. (1978). Fiziksel Kimya Terimleri Sözlüğ̈̈. Ankara 1978.

Somer G. \& Yaşar A. (2009). Kimya Terimleri Sözlüğ̈̈. Ankara 2009.

Tan N. (2001) Kuruluşunun 70. Yıl Dönümünde Türk Dil Kurumu. Ankara 2001.

Üneri S., Kuleli Ö. \& Gürel O. (1981). Kimya Terimleri Sözlüğ̈̈. Ankara 1981.

Zülfikar H. (1991). Terim Sorunlart ve Terim Yapma Yollart. Ankara 1991.

Zülfikar H. (2006). “Cumhuriyet Dönemi Terim Çalışmalarına Bir Bakış ve Varılan Son Durum”. Eds. G. Gülsevin \& E. Boz, Türkçenin Çăgdaş Sorunları (2006). İstanbul. 